János Ede Szilágyi, Ph.D., Associate Professor

University of Miskolc

Faculty of Law

celesut@gmail.com

\title{
THE CHANGING CONCEPT OF RURAL COMMUNITY AND ITS IMPORTANCE IN CONNECTION WITH THE TRANSFER OF AGRICULTURAL LAND
}

Abstract: Primarily focusing on the European Union (EU) law and the national law of the Member States of the EU, this paper presents the changing legal concept of rural communities and/or agricultural communities (hereinafter together referred to as rural communities). Since the EU's concept of rural communities is significantly based on the definition provided by the Council of Europe, hence, the paper also asesses the background of the rural communities' concept connected to the Council of Europe, namely, the European Charter for Rural Areas and scientific reports connected to the Charter. The legal definition of rural communities is elementary for Hungary - among others - since the conservation of rural communities was a determining reason at the time of the adoption of the new Hungarian land law. According to the jurisdictions of the Court of Justice of the European Union, certain aspects of the conservation of rural communities shall serve as a legal public interest objective for national measures concerning land transactions. Therefore, this situation raises the question: what does the term 'rural community' mean.

Keywords: rural community - agricultural community - rural law-farmland - acquisition of agricultural land.

The present article ${ }^{1}$ may be regarded as a continuation of the author's articles published in the $4 / 2016^{2}$ and $3 / 2 / 2017^{3}$ issues of the Zbornik Radova. In those

${ }^{1}$ This research was supported by the project nr. EFOP-3.6.2-16-2017-00007, titled Aspects on the development of intelligent, sustainable and inclusive society: social, technological, innovation networks in employment and digital economy. The project has been supported by the European Union, co-financed by the European Social Fund and the budget of Hungary.

${ }^{2}$ See János Ede Szilágyi, "Acquisition of the ownership of agricultural lands in Hungary, taking the EU's and other countries's law into consideration", Zbornik radova Pravnog fakulteta, Novi Sad 4/2016, 1437-1451.

${ }^{3}$ See J. E. Szilágyi, "Cross-border acquisition of the ownership of agricultural lands and some topical issues of the Hungarian law”, Zbornik radova Pravnog fakulteta, Novi Sad 3/2/2017, 1055-1072. 
articles, the author dealt with cross-border acquisition of agricultural land and forest, especially in the EU and in Hungary. The author assessed the legislation of the EU concerning this type of acquisition, and he also focused on the practice of the Court of Justice of the European Union (CJEU) which court has a significant role to interpret the EU's legislation and the compliance of Member States' laws with the EU law.

According to the practice of the CJEU, ${ }_{4}^{4}$ and the interpretation of the European Commission ${ }^{5}$ as well, the Member States shall lawfully apply certain restrictions on fundamental freedoms (in this case, it means especially the free movement of capital and the free movement of persons) in order that Member States may reach their certain agricultural policy objectives. As to agricultural policy objectives that may justify restrictions on fundamental freedoms, during its interpretation, the CJEU - among others - typically refers to Article 39 of the Treaty on the Functioning of the European Union (TFEU), especially Article 39 (1) (b) of the TFEU 6 and Article 39 (2) (a) of the TFEU.7 According to Article 39 (1) (b) of the TFEU, "[t]he objectives of the common agricultural policy shall be:[...] thus to ensure a fair standard of living for the ["]agricultural community[']"; according to Article 39 (2) (a) of the TFEU, "[i]n working out the common agricultural policy and the special methods for its application, account shall be taken of: [...] the particular nature of agricultural activity, which results from the social structure of agriculture and from structural and natural disparities between the various agricultural regions". As a conclusion of its interpretation, the CJEU has recognised a number of national public policy objectives that can in principle justify restrictions to investment in agricultural land; inter alia [a] preserving 'agricultural communities' ${ }^{8}$ and $[\mathrm{b}]$ preserving a 'permanent agricultural community" are also accepted.

It is worth noticing that other denominations referring to '(permanent) agricultural community'10 is also applied at EU level. For example, in the practice of the CJEU: 'farming community', ${ }^{11}$ or in the interpretation of the European Com-

${ }^{4}$ See e.g. CJEU Case C-452/01 Ospelt, Margarethe Ospelt and Schlössle Weissenberg Familienstiftung, Judgement of the Court, 23 September 2003, [ECR] 2003 I-09743; CJEU Case C-370/05, Criminal proceedings against Uwe Kay Festersen, Judgement of the Court, 25 January 2007, [ECR] 2007 I-01129.

${ }^{5}$ European Commission, Commission Interpretative Communication on the Acquisition of Farmland and European Union Law, OJ C 350, 18.10.2017, 5-20 (hereinafter referred to as COM 2017).

${ }^{6}$ Case C-452/01 Ospelt, paragraph 40; Case C-370/05 Festersen, para. 28.

${ }^{7}$ Case C-452/01 Ospelt, paragraph 40; Case C-370/05 Festersen, para. 28.

${ }^{8}$ Case C-452/01 Ospelt, paragraph 39; Case C-370/05 Festersen, para. 31-32.

${ }^{9}$ Case C-370/05 Festersen, para. 27.

${ }^{10}$ In the practice of the CJEU, there are other similar phrases connecting to the agricultural communities. E.g. 'traditional forms of farming' in Case C-370/05 Festersen, para. 27, 30.

${ }^{11}$ Case C-452/01 Ospelt, para. 52. 
mission: 'rural population'. ${ }^{12}$ Taking this variability of denominations into consideration, the author of present article refers to the rural-agricultural-farming communities with the unified denomination of 'rural communities' or 'rural community' in this paper. Knowing that the preservation of rural communities as agricultural policy objective can in principle justify restrictions to investment in agricultural land according to the practice of the CJEU, in present article, the concept and substance of the rural community will be analysed at EU level. During this analysis, the essential questions are whether a uniform concept exists at EU level, and whether a Member State has any competence to determine its own specific rural community concept.

Taking the above-mentioned situation into consideration, first, the present article focuses on the legal document of the Council of Europe (i.e. European Charter for Rural Areas) and the preparatory studies of this Charter (i.e. drafts of Hans Popp). In connection of the document of the Council of Europe, it worth noticing that the European Charter for Rural Areas provided the conceptual basis for the European Union's policy and legislation concerning rural development. Second, the present article concentrates on the second pillar of the Common Agricultural Policy of the European Union, i.e. rural development policy. Third, the legislation framework of the rural development of the EU will be presented in the paper.

\section{AN ANTECEDENT OF THE EUROPEAN UNION RURAL DEVELOPMENT CONCEPT: THE RURAL COMMUNITY CONCEPT OF THE COUNCIL OF EUROPE}

There are numerous antecedents of the present rural development policy of the European Union, but the role of the documents of the Council of Europe is particularly essential. ${ }^{13}$ Especially, the European Charter for Rural Areas ${ }^{14}$ was determining for the European Union's rural development approach.

The European Charter for Rural Areas was adopted after a relatively long preparation process. The preparators of the European Charter for Rural Areas were two outstanding experts of the rural development, i.e. professor Joseph Hudault from France and professzor Hans W. Popp from Switzerland. The latter professor published, in Hungarian, a draft of the European Charter for Rural

\footnotetext{
${ }^{12}$ COM 2017, 9.

${ }^{13}$ István Olajos, A vidékfejlesztési jog kialakulása és története, Novotni Alapítvány, Miskolc 2008, 19-28, 47-234.

${ }^{14}$ In connection with this, see: Council of Europe Parliamentary Assembly Recommendation 1296 (1996) on European Charter for Rural Areas. Text adopted by the Assembly on 23 April 1996 (11th Sitting).
} 
Areas as 'The European fundamental document of the Rurality - second draft, 8 November 1994', ${ }^{15}$ furthermore he also complete this with an explanation. ${ }^{16}$ However, this second draft of the European Charter for Rural Areas "was still too radical for Western countries". ${ }^{17}$

István Olajos has mentioned in this regard that "the European Charter for Rural Areas has in many aspects not taken over numerous virtues and concrete rural development and agrarian policy conceptions of the draft. It avoided to assess those functions which endanger the rural areas... when turning the politics into law, more attention could have been attached to those statements of professor Popp, according to which the Central-Eastern European regions cannot be developed in a unified was, based upon Western-European conceptions." 18

It is important to mention that the European Charter for Rural Areas and the later documents, legal acts of the EU also build the legislation upon the different categories of 'rural areas', and the conception of 'rural communities' does not appear in in a similar depth in the document. In our case nevertheless, the category of 'agricultural communities' - appearing in the use of natural resources in the EU law - is of importance, as their protection may be the lawful reason in EU law to restrain the transfer of agricultural lands. Therefore, it is of importance what kind of a concept the Charter includes in this regard. The Charter deems it significant that "the positive aspects of rural society and in particular of traditional family life should be preserved in order to favour the development of young people and their integration into the community". ${ }^{19}$ The Charter deems it equally important that "community identity should be reinforced", as well as that "the cultural and historical characteristics of the countryside should be preserved" (however, the Charter does not aim at hermetically blocking rural population from other communities of the society!). ${ }^{20}$ In this regard, professor Popp has also drew the attention to the fact that "here and there tensions arise due to the unsatisfying integration of those running away from the cities and wishing to install in rural areas (greenbelt)"; professor Popp also mentions that - with regard to the rural population's self-consciousness and self-reliance - its citizens "become both politically and culturally influenced by foreigners". Hence, danger is that one of the most precious particularities of rural life may disappear". ${ }^{21}$ This observation of professor Popp may seem interesting especially with regard to the - Cork 2.0 Declaration (to be presented later).

\footnotetext{
${ }^{15}$ See Hans Popp, Földszolgálat, Agroinform Kiadóház, Budapest 2002, 127-139.

${ }^{16}$ Ibid., 109-126.

${ }^{17}$ Words of Györi-Nagy Sándor were cited in H. Popp, 10.

${ }^{18}$ I. Olajos, 23.

${ }^{19}$ Recommendation 1296 (1996), Appendix 2, Guideline 1 (Principles).

${ }^{20}$ Recommendation 1296 (1996), Appendix 2, Guideline 1 (Principles).

${ }^{21}$ H. Popp, 130.
} 
Coming back to the finally adopted text of the European Charter for Rural Areas, the Charter aims at "giving priority to those activities and initiatives that are geared towards endogenous development and above all are managed and financed by the rural community itself". ${ }^{22}$ The Charter names as a significant task or function of a multifunctional agriculture to preserve "rural values, lifestyles, cultural assets and similar social functions for the community". ${ }^{23}$ The Charter deems important "enhancing...the rural historical and cultural heritage, strengthening the regional cultural identity of rural inhabitants and stimulating community activities" ${ }^{24}$ Guideline 15 - a forward-looking guideline - draws the attention to the particularities of the rural areas of Central and Eastern Europe, and, hence, to a management of these problems taking the differences into consideration. The Charter gives a great freedom to the countries of this region when choosing their special policy and measures. Solidarity and co-operation are called for. ${ }^{25}$ The Cork 2.0 Declaration has not taken over this expressis verbis differentiation.

The above-mentioned parts of the Charter draw the concept of a determined and classic rural community. We deemed their detailed description important as other, later assessed documents do not, or hardly include similar notions, but more of them refer (directly or indirectly) to the European Charter for Rural Areas.

\section{RURAL COMMUNITIES IN THE RURAL DEVELOPMENT POLICY OF THE EUROPEAN UNION AS WELL AS IN ITS RELATED LEGAL ACTS}

In the followings, first, the changes related to the rural communities' concept in rural development policy, and, afterwards, the concerning EU law is to be assessed.

\subsection{The concept of rural communities in the $\mathrm{EU}$ policy}

The basis for the European Union's rural development programme is the Cork Declaration towards an integrated rural development policy, ${ }^{26}$ which is expressly based on the rural development materials of the Council of Europe. The Cork Declaration itself came into being in a very interesting way. As it was not adopted by a main organ of the EU (as it is typical in the case of other strategic documents), but a conference was organised during the Irish presidency, ${ }^{27}$ where

${ }^{22}$ Recommendation 1296 (1996), Appendix 2, Guideline 5 (Employment and incomes).

${ }^{23}$ Recommendation 1296 (1996), Appendix 2, Guideline 6 (Agriculture and agricultural policy).

${ }^{24}$ Recommendation 1296 (1996), Appendix 2, Guideline 11 (Culture).

${ }^{25}$ Recommendation 1296 (1996), Appendix 2, Guideline 15 (Central and eastern Europe).

${ }^{26}$ The Cork Declaration - Towards an integrated rural development policy, 9th November 1996.

${ }^{27}$ European Conference on Rural Development, EU, Cork, 7-9.11.1996. 
the participating persons were those who adopted officially the declaration, strengthening the grassroots feature of rural development. The notion of viable 'rural communities' appears in the declaration itself, but practically no concrete content is attached to it. So, the Cork Declaration itself may seem rather neutral (little bit empty), which moderation nevertheless may be explained as this way each member state's variegation has a possibility. However, the Council of Europe's European Charter for Rural Areas may be relied upon in this regard as well.

For two further decades we cannot talk of any significant development concerning the concept of rural communities. However, when the Cork 2.0 Declaration $^{28}$ was adopted, a new rural community concept appeared. But first, we are coming to the studies which preceded the Cork Declaration.

In this case, 'preceding' means the followings. The Cork Declaration did not count with immigration with regard to rural communities. We have already mentioned that in the working papers of the Council of Europe serving as a background of the Cork Declaration any foreign elements entering the local community appears rather as a danger. However, before the new, Cork 2.0 Declaration, the European Network for Rural Development (ENRD) founded by the European Commission has published documents financed by the European Commission ${ }^{29}$ on the integration of migration into rural development policy as well as the integration of migrants into the rural communities. Therefore, these documents may also be of importance.

\subsubsection{ENRD documents foreshadowing the new concept of rural communities}

The European Network for Rural Development (ENRD) was established by the European Commission's AGRI DG in 2008, which makes a certain framework for a more effective exchange of experience of persons and experts related to rural development. ${ }^{30}$

It was not during the illegal mass migration crisis of 2015 when the questions related to immigration have first appeared in the ENRD documents, but already

${ }^{28}$ Cork 2.0 Declaration - „, A Better Life in Rural Areas”, Publications Office of the European Union, Luxembourg, 2016.

${ }^{29}$ See for example:

Migrant and refugee integration (ed.: Matthias Langemeyer), Publications Office of the European Union, Luxembourg July 2016, doi:10.2762/21927; Examples of projects supporting social inclusion (ed.: Rob Peters), Publications Office of the European Union, [-] June 2013, K3AK-13-001-EN-C; ENRD, How to support social inclusion of migrants and asylum seekers, Factsheet, prepared for the ENRD Workshop (in Brussels on 17 March 2016) on LEADER/CLLD and Networking in Support of Social Inclusion, June 2016, https://enrd.ec.europa.eu/sites/enrd/files/ w8_factsheet3_migrants.pdf, (hereinafter referred to as ENRD (2016a)).

${ }^{30}$ About the precise operation of the ENRD, see ENRD, Connecting rural Europe 2014-2020, What is rural networking?, European Union February 2016. 
beforehand. In the followings, we are going through the related documents until the adoption of the Cork 2.0 Declaration.

The ENRD has already published a rural development report supporting migration, even before the current 2014-2020 budgetary period of the EU, i.e. before the adoption of the EU legal material serving as its basis, namely in the previous, 2007-2013 budgetary period. A so-called project brochure of June 2013, head-edited by a leader of the European Commission's AGRI DG ${ }^{31}$ published a Swedish model on social inclusion to be followed in this regard, which took place in Borlänge, which accepts yearly 400 migrants from Somalia, Iraq, Kosovo and Azerbaijan, and tried to involve them in their works. ${ }^{32}$ In the project brochure social inclusion is introduced with referring to numerous rural development projects of the 2007-2013 budgetary period in which they tried to achieve the amelioration of the quality of rural life through social inclusion. The during the social inclusion determined target groups of priority are among others the children in need, persons with disabilities, old, small-scale farmers living in poverty, migrants and ethnic groups like the romas. ${ }^{33}$

In the 2014-2020 budgetary period of the EU - namely in Regulation (EU) No 1305/2013 on support for rural development by the European Agricultural Fund for Rural Development (EAFRD) - priority 6 of the EU rural development policy rules on "promoting social inclusion"; the priority 6 itself nevertheless does not name migration. ${ }^{34}$ In the ENRD documents however, the issue of migration becomes part of the rural community concept through this priority. ${ }^{35}$

${ }^{31}$ The goal of the similar project brochures are to promote experience-sharig by presenting rural development projects financed by the European Union; M. Langemeyer, impressum.

${ }^{32}$ R. Peters, 14-15.

${ }^{33}$ R. Peters, 3.

${ }^{34}$ According to Article 5 of Regulation (EU) No 1305/2013 of the European Parliament and of the Council:

"The achievement of the objectives of rural development, which contribute to the Europe 2020 strategy for smart, sustainable and inclusive growth, shall be pursued through the following six Union priorities for rural development, which reflect the relevant Thematic Objectives of the CSF: [...]

(6) promoting social inclusion, poverty reduction and economic development in rural areas, with a focus on the following areas: (a) facilitating diversification, creation and development of small enterprises, as well as job creation; (b) fostering local development in rural areas; (c) enhancing the accessibility, use and quality of information and communication technologies (ICT) in rural areas [...]

Programmes may address fewer than six priorities if justified on the basis of the analysis of the situation in terms of strengths, weaknesses, opportunities and threats ("the SWOT") and the ex ante evaluation. At least four priorities shall be addressed by each programme."

To present an unambiguous situation, it is worth noticing that the previous rural development regulation, i.e. Council Regulation (EU) No 1698/2005, did not include similar priority.

${ }^{35}$ See: https://enrd.ec.europa.eu/thematic-work/social-inclusion_en, 15 December 2018. 
In this regard, a significant step was the establishment of a so-called NRN cluster on a 2016 ENRD meeting (so-called conference NRN 4), organised between February 29 and March 1, 2016. The NRN abbreviation refers to National Rural Networks functioning in the member states of the EU, while the NRN meeting is an event organised for these national rural networks, enabling the exchange of experiences and cooperation. According to this report on the NRN 4 of $2016^{36}$ as well as the thematic webpage of the ENRD, ${ }^{37}$ the meeting had a special section dedicated to social inclusion, the establishment of which section was initiated by the Swedish national rural development network. At the beginning of the section, a high-level official of the European Commission, Matthias Langemeyer" "explained the expectation from the Commission (sic!) with regard to the integration of migrants. The Commission would like Member States to use the RDP in a flexible way to welcome refugees and deal with social inclusion. He urged networks to send relevant examples supported by the previous programme." So, we can easily conclude that in reality, it was the Commission's proposal to include migration into RDP and a so far ideologically neutral rural conception became ideologically orientated. (It has to be mentioned that the report uses most often the category 'migrant', and, sometimes, the category 'refugee'.) Afterwards, the session continued with a roundtable, on which the Finnish, German, Slovenian, Greek and Swedish participants shared their situations, as well as their challenges and experiences on the social inclusion of migrants with each other.

After that, some of the national rural networks - Finland, Germany and Sweden - has decided to set up a platform (later referred to as NRN cluster), in order to perpetuate the exchange of experiences on the topic. ${ }^{39}$ Next step was a

${ }^{36}$ ENRD: 4th NRN meeting - Improving RDP implementation through networking, 29 February - 1 March 2016, Bled (Slovenia), 13, 19, https://enrd.ec.europa.eu/sites/enrd/files/final-report_4thnrnmtg_0.pdf, 15 December 2018 (hereinafter referred to as ENRD (2016b))

${ }^{37}$ See: https://enrd.ec.europa.eu/thematic-work/social-inclusion_en, 15 December 2018.

${ }^{38}$ Matthias Langemeyer - among others - as an expert dealt with the land law of the new Member States of the EU; see Richard Grover et al, European Union accession and land tenure data in Central and Eastern Europe, FAO Land Tenure Policy Series 1, FAO, Rome 2006, http:// www.fao.org/3/a-a0464e.pdf, 15 December 2018.

${ }^{39}$ ENRD (2016b), 19:

"The session was initiated and facilitated by the Swedish NRN. At the start of the session Matthias Langemeyer (DG AGRI) explained the expectation from the Commission with regard to the integration of migrants. The Commission would like Member States to use the RDP in a flexible way to welcome refugees and deal with social inclusion. He urged networks to send relevant examples supported by the previous programme.

The Open Space discussion was continued with a 'round the table' session where all participants (representatives from Finland, Germany, Slovenia, Greece, Sweden) talked about their situation and their challenges and experience of social inclusion of refugees. Among others:

- Finland had a seminar in January on the theme (and they also have a number of LEADER projects); 
so-called think tank platform (i.e. a previously determined NRN cluster) on June 3, 2016 among the Swedish, the German and the Finnish network. Coordinator of the work of the NRN cluster was Nils Lagerroth of the Swedish national rural development network. ${ }^{40}$

Following the 4th NRN meeting, in March 2016 a 'workshop' took place, for which the ENRD (dated June 2016 (sic!)) published a factsheet, in order to facilitate the preparation, which bore the title "How to support the social inclusion of migrants and asylum seekers?". ${ }^{41}$ According to the factsheet, economic migrants are nowadays a cornerstone of the rural economy. According to this report, 'economic migrants' are (a) workers in the EU moving among the Member States, (b) legal/regular migrants coming from third countries, and (c) undocumented migrants arriving on the territory of the EU. ${ }^{42}$

The factsheet, furthermore, deals separately (not included in the economic migrant category) with the asylum seekers (not to be confused with refugees!) having streamed in during the 2015 refugee/illegal migrants crisis, who are esteemed to be over 1.000.000, and who are counted with as all of them would have come from a country stricken by war. The factsheet draws the attention to the fact that the asylum seekers' rights and prospects are differing, but as long as they do not receive the refugee status, they cannot work. Therefore, until their fate was decided, they were in large numbers placed to refugee camps to be found in rural areas throughout Europe. The factsheet brings many examples where more asylum

- In Slovenia they try to promote the integration of migrants, and encourage LAGs to initiate projects;

- In Germany a workshop will be organised on the topic in April 2016, and a pool of good practices is collected;

- In Sweden the Steering Group considered the topic a top priority; and there have been links between farmers and immigrants (in order to find immigrants with the right skills and know-how). Good practice examples are currently collected, and a LEADER conference will be organised in April;

- Greece has a slightly different context, as immigrants often just enter the country, but would like to settle elsewhere. In the draft call for LAGs there is the possibility to take actions to address the immigration crisis but depends on their local strategy if they will use this possibility....

Some of the networks including Finland, Germany and Sweden plan to set up a platform for regular exchange of experience and also a possibility to ask colleagues about advice on social inclusion. This platform may be arranged as periodical video or telephone meetings with a pre-defined agenda."

${ }^{40}$ See: https://enrd.ec.europa.eu/thematic-work/social-inclusion_en, 15 December 2018.

About the concept of the Swedish national rural development network, see ENRD, What can National Rural Networks do to support social inclusion?, Factsheet, prepared for the ENRD Workshop (in Brussels on 17 March 2016) on LEADER/CLLD and Networking in Support of Social Inclusion, June 2016, 2, https://enrd.ec.europa.eu/sites/enrd/files/w8_factsheet5_networking.pdf, 15 December 2018.

${ }^{41} \operatorname{ENRD}$ (2016a).

${ }^{42}$ The factsheet applies the denomination 'undocumented' referring even to illegal migrants; Ibid., 1. 
seekers were placed in a Swedish village than the number of actual inhabitants of the given village (sometimes even multiple times the number of inhabitants). The factsheet afterwards highlights the potential positive effects of placing the economic migrants and asylum seekers in rural areas and their planned integration.

In order to make these positive effects effective, the factsheet would like to realize the integration of migrants in rural areas in four steps. First, in the local population, an "attitude of welcome" has to be reinforced for a mutual understanding and trust. In a second step to abolish barriers arising from not knowing the language, from the lack of qualification and proper practice, and from not being acquainted with the law. Although the factsheet does not say, but presumably these shortfalls appear on the side of the asylum seekers and not the local inhabitants. Third, the opportunity has to be given so that the migrants may care for themselves on the long term. Fourth, accommodation, health care, education, social allowances and any other things have to be provided for the migrants, so that they would suffer no needs. ${ }^{43}$

After all this, the factsheet goes through those rural development projects which may help the social integration of migrants and asylum seekers, i.e. the factsheet details how the rural development supports may be used to fulfil the needs of migrants and asylum seekers. Meanwhile, the factsheet mentions already realized or planned good practices as well as good practices done by volunteers. ${ }^{44}$ Afterwards, the factsheet draws up what should be done at local, national and EU level. At national level for example, it is described as task of the given authorities to raise awareness in the local networks and stakeholders about the social integration of migrants and asylum seekers. Similarly, at national level it is described as the task of the national rural development networks to take actively part at the exchange of experience; the Swedish model is named as an example in this part as well. ${ }^{45}$

The draft of the project brochure ${ }^{46}$ - which was edited by Matthias Langemeyer, the very high representative of the Commission who explained the expectations of the European Commission upon the integration of the migrants ${ }^{47}$ to the participants of the 4th NRN meeting's session dealing with social integration - was closed not much later (in July 2016) than the creation of the Swedish-Finnish-German cluster and the publication of the workshop factsheet. The aim of the project brochure 'Migrant and Refugee Integration'48 is, first, to explain how people living in rural areas used the EAFRD supports in response to the challenges and opportunities arising from the actual "migrant and refugee influx", and, second,

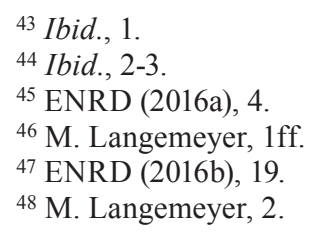


to ensure a lot more positive picture - through the example of some European rural areas - to the appropriate management of the situation.

The project brochure technically starts with the situation, according to which Europe and its rural territories within are going to face soon huge demographic challenges due to its ageing population. A solution is named for this - practically in harmony with the UN's 2001 "Replacement migration" report ${ }^{49}$ - as: migration. ${ }^{50}$ Besides, according to the project brochure, the EU's member states have a significant autonomy as to how to handle asylum seekers and refugees, and underlines also that integration is a two-way process, which should be wanted both by the integrating community and the newcomers. The project brochure talks about the NRN cluster created during the $4^{\text {th }}$ NRN meeting with regard to the social integration of migrants and refugees, as well as that it is open to other participants, and draws the attention to the fact that there exist plans on other supranational cooperation projects in this issue, and that the Finnish, Austrian and Swedish partners can be counted on. ${ }^{51}$ Afterwards, the project brochure focuses on EAFRD-financed projects which - as good local practices - serve as an example for other states, showing how we can do for the social integration of migrants and refugees in rural areas.

Eight countries serve as good rural development examples; namely, Austria, Finland, Germany, Greece, Italy, Luxembourg, Sweden and United Kingdom. The good practices appearing in the project brochure are split into three main groups. The first group received the name "Changing the narrative", and contains projects which develop awareness and understanding between migrants and local communities. In these projects, the use of arts and culture are essential, just like many activities pursued together, which bring the communities closer to each other and relieve the barriers between them.

The second group is entitled „Practice and labour market”. It contains projects which prepare the migrants for entering the labour market. Key questions vary from developing language skills to works with employers during which the use of the migrants' abilities and experiences is encouraged. The third group is entitled "Coordinated responses" and contains projects in which it was recognized that coordinated responses have to be given to the complex needs of the people; so, that they have access to employment, services and social-cultural life. To these projects belongs for instance the employment of so-called integration coordinators. ${ }^{52}$ It has

${ }^{49}$ UN Secretariat, Replacement Migration - Is It a Solution to Declining and Ageing Populations?, UN Secretariat Department of Economic and Social Affairs Population Division, ST/ ESA/SER.A/206, [-], UN, 2001, http://www.un.org/en/development/desa/population/publications/ ageing/replacement-migration.shtml, 14 April 2018.

${ }^{50} \mathrm{M}$. Langemeyer, 2.

${ }^{51}$ Ibid., 3.

${ }^{52}$ Ibid., 4., 5-28. 
to be highlighted that a significant part of the projects belongs to the so-called LEADER type of the rural development supports. It is as the LEADER type supports provide the biggest flexibility as to the use of EU rural development money ${ }^{53}$ The project brochure furthermore draws the attention ${ }^{54}$ to brochure made by the EurEcademy Association for NGOs ${ }^{55}$ which was published in 2016, and which could be of great help for the future of social integration.

\subsubsection{The circumstances of the adoption of the Cork 2.0 Declaration}

The conference organised for the adoption of Cork 2.0 Declaration, approximately 340 interested have been present, whose task was to - as in the case of the Cork Declaration - in a grass rooted way, during the two days of the conference prepare the new rural development policy of 20 years for the European Union. The participants followed their work in four working groups. According to the materials of the conference ${ }^{56}$ the new concept of rural communities, that building upon migration could receive more attention in the fourth working group.

A Swedish expert, Hans-Olof Stålgren, wrote an introduction to the work of the fourth commission, in which he devotes a significant part to the depopulation of rural areas. As he writes: "Young people leave, especially young women, creating a demographic problem with less and older population. There is something often called 'the urban norm' suggesting that, 'To be somebody and to achieve something you have to live in the city'. That is the message and attitude in many cases. But there are also people searching for other ways of living, in the countryside." ${ }^{57}$ Stålgren comes to migration with regard to this topic. As to the category of 'migrant' - as seen in the previous, ENRD material, too - for him as well, the movement of EU citizens in the EU, and those coming from outside the Union are one category; and. furthermore, even refugees appear under the category of migrants. Afterwards, Stålgren connects the depopulation of rural areas with migration: "So we have on the one side a lack of people in rural areas and on the other side people knocking at our door to come in. Could these two needs match each other? With an engaged rural community, the integration seems easier than

${ }^{53}$ Ibid., 4.

${ }^{54}$ Ibid., 4.

55 A Capacity Building Manual for NGOs Promoting the Integration of Migrants and Refugees in Rural Areas (ed.: Fouli Papageorgiou et al), EurAcademy Thematic Guide Series 13, [-], EurAcademy Association, 2016, http://www.euracademy.org/wp-content/uploads/2016/03/ThematicGuide13_eng-1.pdf, 15 December 2018.

${ }^{56}$ See the website of the conference: https://ec.europa.eu/agriculture/events/rural-development-2016_en, 15 December 2018.

${ }^{57}$ Hans-Olof Stålgren, Introduction to Workshop 4 - Rural viability and vitality, Cork 2.0: European Conference on Rural Development on 5-6 September 2016, 2., https:/lec.europa.eu/ agriculture/sites/agriculture/files/events/2016/rural-development/stalgren_en.pdf, 15 December 2018. 
in an urban, quite segregated, setting. What competences and skills do newcomers have that are needed in rural communities? Can the welcoming of refugees be an investment for rural areas?"58 The material of Carmen Hubbard served equally as an introduction to the fourth working group. ${ }^{59}$ In this, Hubbard mentions among the beneficiaries of EU development money the refugees and legal migrants. Furthermore, with regard to the planned renewal of the EAFRD, questions arise in this regard: "Are rural areas across member states ready to embrace and integrate newcomers? How can we guarantee that refugees and other migrants, especially those who have been re-settled in remote rural areas (e.g. the Scottish Islands), feel 'at home' and part of the communities, rather than being isolated, lost and forgotten?" 60

The first point of the Cork 2.0 Declaration, entitled "Promoting Rural Prosperity", shows a significant change in the concept of rural community compared to the Cork Declaration:

"The rural potential to deliver innovative, inclusive and sustainable solutions for current and future societal challenges such as economic prosperity, food security, climate change, resource management, social inclusion, and integration of migrants should be better recognised. A rural proofing mechanism should ensure this is reflected in Union policies and strategies. Rural and agricultural policies should build on the identity and dynamism of rural areas through the implementation of integrated strategies and multi-sectorial approaches. They should promote diversification and foster entrepreneurship, investment, innovation and employment. These policies should also give value to rural identity and enhance sustainability, social inclusion and local development, as well as the resilience of farms and rural communities."

It has to be highlighted that apart from the above, rural communities are mentioned in other parts of the Cork 2.0 Declaration; its points 7 and 8 also mention 'rural communities', but a concrete definition - apart from the declaration that now the settling of migrants in rural areas is supported - continues to be lacking, so, therefore, it may still be the European Charter for Rural Areas which may help those interested with regard to the concept of rural communities. Here, nevertheless, we may see a serious contradiction between the concept of the European Charter for Rural Areas (especially read together with Hans Popp's explanations) - i.e. the traditional transfer of the heritage of the rural community between the generations - and the concept of the Cork 2.0 Declaration on rural communities.

${ }^{58}$ H.-O. Stålgren, 2.

${ }^{59}$ Carmen Hubbard: Workshop 4: Encouraging and Supporting Rural Vitality - Introduction to Day 2 Cork 2.0, Cork 2.0: European Conference on Rural Development on 5-6 September 2016, https://ec.europa.eu/agriculture/sites/agriculture/files/events/2016/rural-development/ws4-hubbard_ en.pdf

${ }^{60}$ C. Hubbard, 2. 
However, as to the adoption of the Cork 2.0 Declaration, there was a participant who deemed it strange to have prepared a document determining the rural development policy of the whole European Union in such a short time by people coming from the widest parts of Europe: "we were deceived... I.e. no avail to the efforts of the professional moderators and the participants, but so much time is too short to form serious thoughts. Indeed, it is also questionable whether those responsible put together in a few hours the text of the declaration which was finally proclaimed based on the things which were discussed there." 61

This remark might have been not alone-standing, as in the 2016 autumn number of the ENRD's periodicals, the so-called Rural Connections, a special part was dedicated to the circumstances of the adoption of the Cork 2.0 Declaration, and they deemed it important to quote the general reporter of the first work group of the Cork 2.0 Conference, namely: "As someone who has been involved from the very outset, I can assure you that [the Declaration] was not pre-[written].... All the information gathered in the groups went back to the drafting team." 62 The ENRD in its newsletter on the adoption of the Cork 2.0 also deemed it important to publish the declaration of the president of the drafting committee in this regard: "I am sure many people did not expect this kind of active engagement, which on the other hand created quite a challenge for us who were in charge of drafting the Declaration. We collected the information on each round of work with the group facilitators. Two experts from each workshop also took part in the effort to draft the Declaration." 63 Here, those lines written with regard to the $4^{\text {th }}$ NRN meeting are worth to be referred to (see above).

The Cork 2.0 Declaration, i.e. a EU strategy adopted this - even in the European Union highly unusual - way has nevertheless received a particular importance through the agricultural commissioner of the European Commission: "As Commissioner for Agriculture and Rural Development, I accept this Declaration and will give it most serious consideration. It is a strong Declaration, rich in content and intent. It reflects the needs and aspirations of the rural and agricul-

${ }^{61}$ Reszkető Tímea: Vidékfejlesztési politika újratöltve, 12.09.2016; http://gazdablog.hu/blog/ videkfejlesztesi_politika_ujratoltve

62 "As someone who has been involved from the very outset, I can assure you that [the Declaration] was not pre-[written].... All the information gathered in the groups went back to the drafting team." The opinion of Alan Jagoe was cited by Rural Connections, autumn/2016, 18, https://enrd.ec.europa.eu/sites/enrd/files/publi-enrd-magazine05-2016-en.pdf, 15 December 2018.

63 "I am sure many people did not expect this kind of active engagement, which on the other hand created quite a challenge for us who were in charge of drafting the Declaration. We collected the information on each round of work with the group facilitators. Two experts from each workshop also took part in the effort to draft the Declaration." The thought of Heino von Meyer was referred by ENRD, European Conference on Rural Development, Special Edition Newsletter, September/2016, 1, https://enrd.ec.europa.eu/sites/enrd/files/cork_newsletter-web_en.pdf, 15 December 2018 (hereinafter referred to ENRD (2016c)). 
tural communities, and it gives strong recommendations on the kind of policies needed to unleash the rural potential. I believe it provides an important input and orientation for the up-coming debates on the future of our rural and agricultural policies and I count on your continued involvement and support to ensure that we have a strong CAP that is fit for purpose, accountable, and capable of addressing the challenges and opportunities of the 21st century." 64

After the adoption of the Cork 2.0 Declaration, the preparation of the implementation of the strategic document has started. So, for instance in the $6^{\text {th }}$ NRN meeting (November 8-9, 2016, Senec, Slovakia) they assessed how the national rural development networks may take part in the realization of the conceptions contained in the Cork 2.0 Declaration. In this regard we have to mention that the topic of the social integration of asylum seekers and migrants (with reference to the many times cited Swedish example) does not appear at the Point 1 of the Cork 2.0 Declaration, ${ }^{65}$ but at its Point 3, entitled "Investing in Rural Viability and Vitality". 66

In the summary of a not much later, on December 1, 2016 in Brussels organised third meeting of the Assembly of the European Network for Rural Development, following this logic, migration questions have been treated under Point 3 of the Cork 2.0 Declaration. Here, the NRN cluster, which was initiated by the Swedish national rural development network and the topic of which was found according to the expectations of the European Commission (sic!), is brought up as an already realized action, and as future ideas are enumerated activities which help the migrants or refugees stay at the rural territories; a plan for the future is furthermore to show (like in a roundtrip) the - previously showed - photo exhibition of the ENRD about migrants and refugees in numerous places. ${ }^{67}$

64 "As Commissioner for Agriculture and Rural Development, I accept this Declaration and will give it most serious consideration. It is a strong Declaration, rich in content and intent. It reflects the needs and aspirations of the rural and agricultural communities, and it gives strong recommendations on the kind of policies needed to unleash the rural potential. I believe it provides an important input and orientation for the up-coming debates on the future of our rural and agricultural policies and I count on your continued involvement and support to ensure that we have a strong CAP that is fit for purpose, accountable, and capable of addressing the challenges and opportunities of the 21st century." The thought of Phil Hogan was referred by ENRD (2016c), 1.

${ }^{65}$ In a document of the European Commission published in March 2017, the NRN meeting established in connection with the topic of migration and asylum seekers was mentioned again; see European Commission, Cork 2.0 Action Plan, version March 2017, 2, https://ec.europa.eu/ agriculture/sites/agriculture/files/events/2016/rural-development/cork-action-plan_en.pdf, 15 December 2018.

${ }^{66}$ ENRD: Linkages between NRNs' activities and the 10 policy orientations set out in the Cork 2.0 Declaration, 6 th NRNs' meeting of 8-9 November 2016 in Senec, 1, https://enrd.ec.europa.eu/sites/enrd/files/cork-related-nrn-activities.pdf, 15 December 2018.

${ }^{67}$ ENRD: Discussion summary, 3rd Rural Networks' Assembly of 1 December 2016, 2, https:// enrd.ec.europa.eu/sites/enrd/files/rn-assembly3_network-activities-cork.pdf, 15 December 2018. 


\subsection{Local community as an object of legislation in the EU law}

But what do we need to get to know the exact content of these concepts? Well, according to Article 39 of the TFEU, objective of the Common Agricultural Policy is "to ensure a fair standard of living for the agricultural community, in particular by increasing the individual earnings of persons engaged in agriculture". This is going to be the notion which has to be interpreted by a member state in order for example to lawfully restricting the transfer of agricultural lands. Detailed norms are however not contained in the TFEU in this regard. To a certain extent, though, the CJEU has interpreted Article 39 TFEU in its jurisprudence, e.g. especially as to the lawfulness of the restrictions of the transfer of agricultural lands. ${ }^{68}$

In this regard, the CJEU uses the following terms in its jurisprudence as to rural (agricultural) communities: to preserve agricultural communities, ${ }^{69}$ to preserve a permanent agricultural community, ${ }^{70}$ to maintain, for town and country planning or regional planning purposes and in the general interest, a permanent population and an economic activity independent of the tourist sector in certain regions. ${ }^{71}$ Nevertheless, the fact that 'rural communities' appear often in the jurisprudence of the EU dos not mean that the CJEU would interpret the notion. It took it rather for granted. Therefore, it is unclear, what exactly does the possibility of lawful restriction contained in the TFEU (Article 39) extend to. ${ }^{72}$

${ }^{68}$ The analysis of this jurisprudence is published in numerous high-quality articles; among others, see Tamás Andréka, István Olajos, "A földforgalmi jogalkotás és jogalkalmazás végrehajtása kapcsán felmerült jogi problémák elemzése”, Magyar Jog 7-8/2017, 410-424; Krisztina Bányai, "Theoretical and practical issues of restraints of land acquisition in Hungary", Journal of Agricultural and Environmental Law (JAEL) 20/2016, 8-11; Csilla Csák, "Die ungarische Regulierung der Eigentums- und Nutzungsverhältnisse des Ackerbodens nach dem Beitritt zur Europäischen Union”, JAEL 9/2010, 20-31; Csilla Csák, Bianka Kocsis, Anikó Raisz, "Vectors and indicators of agricultural policy and law from the point of view of the agricultural land structure", JAEL 19/2015, 32-43; Ágoston Korom, Réka Bokor, “Gondolatok az új tagállamok birtokpolitikájával kapcsolatban”, Honori et Virtuti (ed.: Klára Gellén), Iurisperitus, Szeged 2017, 259-267; Á. Korom, "A földpiacra vonatkozó kettős jogalap tételének bírálata", Magyar Jog 3/2011, 152-159; Mihály Kurucz, "Gondolatok a magyar földforgalmi törvény uniós feszültségpontjainak kérdéseiröl", $A$ Magyar Tudomány Napja a Délvidéken 2014 (ed.: József Szalma), VMTT, Novi Sad 2015, 120-173; Aniko Raisz, "Topical issues of the Hungarian land-transfer law", CEDR Journal of Rural Law 1/2017, 69, 73-74; J. E. Szilágyi, "European legislation and Hungarian law regime of transfer of agricultural and forestry lands", JAEL 23/2017, 148-181, doi: 10.21029/JAEL.2017.23.148.

${ }^{69}$ Case C-452/01 Ospelt, para. 39 and 43.

${ }^{70}$ Case C-370/05 Festersen, para. 27 and 28.

${ }^{71}$ Case C-302/97 Konle, para. 40, furthermore Case C-519/99-C-524/99 and Case C-526/ 99-C-540/99 Reisch, para. 34.

${ }^{72}$ It is worth noticing that point 1 e) of COM 2017 uses even the phrase 'to preserve a rural population', in the opinion of the author of the present article, as a synonym of an 'agricultural' one. However, the detailed interpretation concerning rural population cannot be found in the communication. 
We do not get closer to the clearly EU-law based (i.e. different from that of the Council of Europe) determination of the concept of rural (agricultural) communities even if we take a look at the so-called secondary legislation of the European Union. In this regard - as to the legislation in force - especially Regulation (EU) No 1305/2013 of the European Parliament and of the Council on support for rural development by the European Agricultural Fund for Rural Development (EAFRD) could be of great importance. Several of its articles ${ }^{73}$ deal with rural communities, but here, too, we find no exact definition.

On this basis we can conclude that at EU level we cannot find any actual help - apart from referring back to the European Charter for Rural Areas - as to what are rural (agricultural) communities. We have to say it is nothing negative in our view, as it only shows that this competence lays within the member states, we could even say, it is a question of sovereignty (or, in the terminology brought to the public by László Trócsányi, part of our constitutional identity ${ }^{74}$ ), and is connected - though not exclusively - with the population of a country.

\section{CONCLUSION}

To determine the concept 'rural community' of a Member State is the competence of the affected Member State. Taking into consideration all the uncertainties surrounding the determination, for a Member State with an ambitious agricultural policy it is an elementary interest to make use of this competence. The European Commission - in an above-mentioned, strange procedure - changed the concept 'rural community' at the EU's level, namely in the Cork 2.0 Declaration. Although the Cork 2.0 Declaration is a non-binding document, it might be capable to affect the practice of the Court of Justice of the EU. This situation may raise the question whether a Member State could determine the term 'rural community' in a stricter form, namely in a binding legal document. To give a correct and complex answer, the research started in the present article shall be continued.

${ }^{73}$ As an example, see:

Article 4: Within the overall framework of the CAP, support for rural development shall contribute to achieving the following objectives: [...] (c) achieving a balanced territorial development of rural economies and communities including the creation and maintenance of employment; (See furthermore the mentioning of the rural communities at Article 55 (1) d)).

Article 20: 'Basic services and village renewal in rural areas' supports shall cover, in particular: [...] investments in the setting up, improvement or expansion of local basic services for the rural population, including leisure and culture, and the related infrastructure.

Article 43: 'LEADER start-up kit' for local communities.

${ }^{74}$ See: László Trócsányi, “Alkotmányos identitás és európai integráció”, Acta Universitatis Szegediensis Acta Juridica et Politica, 76/2014 473-482; L. Trócsányi, "Nemzeti alkotmányok, európai integráció és alkotmányos identitás”, Acta Universitatis Szegediensis Acta Juridica et Politica 77/2015, 319-328. 


\section{REFERENCES}

Tamás Andréka, István Olajos, “A földforgalmi jogalkotás és jogalkalmazás végrehajtása kapcsán felmerült jogi problémák elemzése”, Magyar Jog 7-8/2017, 410-424

Krisztina Bányai, "Theoretical and practical issues of restraints of land acquisition in Hungary", Journal of Agricultural and Environmental Law 20/2016, 8-11, doi: 10.21029/JAEL.2016.20.5

Csilla Csák, "Die ungarische Regulierung der Eigentums- und Nutzungsverhältnisse des Ackerbodens nach dem Beitritt zur Europäischen Union", Journal of Agricultural and Environmental Law 9/2010, 20-31

Csilla Csák, Bianka Kocsis, Anikó Raisz, "Vectors and indicators of agricultural policy and law from the point of view of the agricultural land structure", Journal of Agricultural and Environmental Law 19/2015, 32-43

ENRD: 4th NRN meeting - Improving RDP implementation through networking, 29 February - 1 March 2016, Bled (Slovenia), 13, 19, https://enrd.ec.europa.eu/sites/ enrd/files/final-report_4thnrnmtg_0.pdf, 15 December 2018

ENRD: Discussion summary, 3rd Rural Networks' Assembly of 1 December 2016, 2, https://enrd.ec.europa.eu/sites/enrd/files/rn-assembly3_network-activities-cork.pdf, 15 December 2018

ENRD, European Conference on Rural Development, Special Edition Newsletter, September/2016, 1, https://enrd.ec.europa.eu/sites/enrd/files/cork_newsletter-web_en.pdf, 15 December 2018

ENRD: Linkages between NRNs' activities and the 10 policy orientations set out in the Cork 2.0 Declaration, 6 th NRNs' meeting of 8-9 November 2016 in Senec, 1, https://enrd.ec.europa.eu/sites/enrd/files/cork-related-nrn-activities.pdf, 15 December 2018

ENRD, What can National Rural Networks do to support social inclusion?, Factsheet, prepared for the ENRD Workshop (in Brussels on 17 March 2016) on LEADER/ CLLD and Networking in Support of Social Inclusion, June 2016, 2, https://enrd. ec.europa.eu/sites/enrd/files/w8_factsheet5_networking.pdf, 15 December 2018

European Commission, Cork 2.0 Action Plan, version March 2017, 2, https://ec.europa. eu/agriculture/sites/agriculture/files/events/2016/rural-development/cork-actionplan_en.pdf, 15 December 2018

Richard Grover et al, European Union accession and land tenure data in Central and Eastern Europe, FAO Land Tenure Policy Series 1, FAO, Rome 2006, http:// www.fao.org/3/a-a0464e.pdf, 15 December 2018

Carmen Hubbard, Workshop 4: Encouraging and Supporting Rural Vitality - Introduction to Day 2 Cork 2.0, Cork 2.0: European Conference on Rural Development on 5-6 September 2016, https://ec.europa.eu/agriculture/sites/agriculture/ files/events/2016/rural-development/ws4-hubbard_en.pdf, 15 December 2018

How to support social inclusion of migrants and asylum seekers, Factsheet, prepared for the ENRD Workshop (in Brussels on 17 March 2016) on LEADER/CLLD and Networking in Support of Social Inclusion, June 2016, https://enrd.ec.europa. eu/sites/enrd/files/w8_factsheet3_migrants.pdf, 15 December 2018 
Ágoston Korom, Réka Bokor, "Gondolatok az új tagállamok birtokpolitikájával kapcsolatban”, Honori et Virtuti (ed.: Klára Gellén), Iurisperitus, Szeged 2017, 259-267

Ágoston Korom, "A földpiacra vonatkozó kettős jogalap tételének bírálata”, Magyar Jog 3/2011, 152-159

Mihály Kurucz, "Gondolatok a magyar földforgalmi törvény uniós feszültségpontjainak kérdéseiről", A Magyar Tudomány Napja a Délvidéken 2014 (ed.: József Szalma), VMTT, Novi Sad 2015, 120-173

Matthias Langemeyer (ed.), Migrant and refugee integration, Publications Office of the European Union, Luxembourg July 2016, doi:10.2762/21927

István Olajos, A vidékfejlesztési jog kialakulása és története, Novotni Alapítvány, Miskolc 2008

Fouli Papageorgiou et al (ed.), A Capacity Building Manual for NGOs Promoting the Integration of Migrants and Refugees in Rural Areas, EurAcademy Thematic Guide Series 13, [-], EurAcademy Association, 2016, http://www.euracademy.org/ wp-content/uploads/2016/03/ThematicGuide13_eng-1.pdf, 15 December 2018

Rob Peters (ed.), Examples of projects supporting social inclusion, Publications Office of the European Union, [-] June 2013, K3-AK-13-001-EN-C; ENRD

Hans Popp, Földszolgálat, Agroinform Kiadóház, Budapest 2002.

Aniko Raisz, "Topical issues of the Hungarian land-transfer law", CEDR Journal of Rural Law 1/2017, 69, 73-74

Reszkető Tímea: Vidékfejlesztési politika újratöltve, 12.09.2016; http://gazdablog.hu/ blog/videkfejlesztesi_politika_ujratoltve, 15 December 2018

Hans-Olof Stålgren, Introduction to Workshop 4 - Rural viability and vitality, Cork 2.0: European Conference on Rural Development on 5-6 September 2016, 2., https://ec.europa.eu/agriculture/sites/agriculture/files/events/2016/rural-development/stalgren en.pdf, 15 December 2018

János Ede Szilágyi, "Ācquisition of the ownership of agricultural lands in Hungary, taking the EU's and other countries's law into consideration", Zbornik radova Pravnog fakulteta, Novi Sad 4/2016, 1437-1451, doi: 10.5937/zrpfns50-12226

János Ede Szilágyi, "Cross-border acquisition of the ownership of agricultural lands and some topical issues of the Hungarian law", Zbornik radova Pravnog fakulteta, Novi Sad 3/2/2017, 1055-1072, doi: 10.5937/zrpfns51-13620

János Ede Szilágyi, "European legislation and Hungarian law regime of transfer of agricultural and forestry lands", Journal of Agricultural and Environmental Law 23/2017, 148-181, doi: 10.21029/JAEL.2017.23.148

László Trócsányi, "Alkotmányos identitás és európai integráció", Acta Universitatis Szegediensis Acta Juridica et Politica 76/2014, 473-482

László Trócsányi, "Nemzeti alkotmányok, európai integráció és alkotmányos identitás", Acta Universitatis Szegediensis Acta Juridica et Politica 77/2015, 319-328

UN Secretariat, Replacement Migration - Is It a Solution to Declining and Ageing Populations?, UN Secretariat Department of Economic and Social Affairs Population Division, ST/ESA/SER.A/206, [-], UN, 2001, http://www.un.org/en/development/desa/population/publications/ageing/replacement-migration.shtml, 14 April 2018 
Dr Janoš Ede Silađi, vanredni profesor

Univerzitet u Miškolcu

Pravni fakultet

celesut@gmail.com

\section{Promena koncepta ruralne zajednice i njegov značaj za prenos svojine na poljoprivrednom zemljištu}

Sažetak: Imajući u vidu pravo Evropske unije (EU) i nacionalna prava država članica EU, u radu je predstvljen koncept ruralnih zajednica $i$ poljoprivrednih zajednica (u radu zajedno označene kao ruralne zajednice), koji je u fazi redefinisanja. Sobzirom na to da se koncept ruralnih zajednica u EU u velikoj meri bazira na definiciji Saveta Evrope, u radu je predstavljeno njegovo poreklo i to na osnovu Evropske povelje o ruralnim područjima i naučnih izveštaja u vezi sa tom Poveljom. Određivanje pravnog pojma ruralnih zajednica je od suštinskog značaja za Mađarsku - između ostalog zbog toga što je njihovo očuvanje bio ključan razlog za donošenje novog mađarskog Zakona o zemljištu. U skladu sa praksom Suda pravde Evropske unije, pojedini aspekti očuvanja ruralnih zajednica predstavljaju javni interes radi čije zaštite se mogu preduzimati odgovarajuće nacionalne mere $u$ vezi sa prometom zemljišta. S tim u vezi se postavlja pitanje: šta se zapravo podrazumeva pod pojmom ruralnih zajednica.

Ključne reči: ruralna zajednica, poljoprivredna zajednica, ruralno pravo, poljoprivredno zemljište, sticanje poljoprivrednog zemljišta.

Datum prijema rada: 23.02.2019. 